\title{
AC 2012-3889: A MODEL FOR THE DEVELOPMENT OF PERSONAL AND PROFESSIONAL SOCIAL RESPONSIBILITY FOR ENGINEERS
}

Nathan E. Canney, University of Colorado, Boulder

Nathan Canney received bachelor's degrees from Seattle University in civil engineering and applied mathematics. After graduation, he worked for Magnusson Klemencic Associates in Seattle, Wash., as a Structural Engineer on high-rise residential buildings. Canney returned to school at Stanford University for a master's degree and is currently pursuing a doctoral degree at the University of Colorado, Boulder, in civil engineering, with an engineering education research focus.

Dr. Angela R. Bielefeldt, University of Colorado, Boulder 


\title{
A Model for the Development of Personal and Professional Social Responsibility for Engineers
}

\begin{abstract}
Important attributes for engineering professionals include an understanding of the global and societal impacts of engineering projects and a well-developed professional and ethical code of responsibility; these attributes must be developed in engineering students. Furthermore, the role of an engineer is becoming increasingly global, requiring an international perspective and crosscultural skills. The core foundation for these skills can be found in a well-developed sense of social responsibility, contextualized by the engineering profession. In this paper a new model for the development of personal and professional social responsibility is proposed, the Professional Social Responsibility Development Model. This model is a combination of three existing theoretical models describing altruistic behavior development, commitment levels to social issues and volunteering, and the integration of social issues into scientific processes. The first generation of an assessment tool based upon the constructs of the development model has been designed. The reliability of the assessment tool is established through test-retest and internal consistency, while validity is established by content and construct validity methods. Based upon the reliability and validity results, further development of this assessment tool is underway in order to develop a tool which can be used to assess engineering students' understanding of social responsibility from multiple disciplines and academic years in a pre-post format.
\end{abstract}

\section{Introduction}

Many professional engineering societies such as the National Academy of Engineering ${ }^{1}$, the American Academy of Environmental Engineers ${ }^{2}$, and the American Society of Civil Engineers ${ }^{3}$ have identified the need to develop more holistic engineers, armed with both technical and professional skills, to address the complex global problems facing our society. The Engineering Accreditation Commission of ABET has set forth eleven metrics in "criterion c" of the criteria for evaluation for the training of engineering students consisting of both technical and professional skills ${ }^{4}$. Two of the professional skills that they list include an understanding of the global and societal contexts for engineering solutions and of professional and ethical responsibility which will guide engineering students as professionals. Furthermore, outcome 22 of the American Society of Civil Engineers (ASCE) Body of Knowledge 2 (BOK2) indicates that attitudes conducive to the effective practice of civil engineering include "consideration of others, ... respect, self-esteem, sensitivity, thoughtfulness, thoroughness and tolerance",3. A developed sense of social responsibility, both personal and professional, contextualized within the engineering profession, encompasses these skills and would create an engineering body which views all of its projects as a service to society. The BOK2 acknowledges that measuring these skills is difficult.

Social responsibility is seen as an obligation that an individual (or company) has to "act with concern and sensitivity, aware of the impacts of their action on others, particularly the disadvantaged" 5 . Social responsibility can be viewed as a continuum. On the one end, an individual has absolutely no understanding or concern about the impacts of their work. Somewhere in the middle, an individual perhaps has an intellectual or removed understanding 
that there are impacts and would consider them if obligated, but has not personalized the social obligation. At the other end is an individual who believes wholly that engineers should work to serve their community and moreover this individual would act accordingly by working for/with philanthropic groups such as Engineers Without Borders (EWB) and Bridges to Prosperity.

This view of engineering as inherently a service has been echoed in Ethics of Care literature ${ }^{6,7}$. Ethics of Care is rooted in the view that moral development is motivated by compassion and caring for others, in addition to the traditional beliefs of motivation through justice or fairness ${ }^{6,8}$. Additionally, views of social responsibly align well with the emerging development of Humanitarian Engineering as a new pedagogical tool for educating more holistic engineers ${ }^{9}$. The philosophy behind Humanitarian Engineering is to use engineering skills to address the social and development problems of underserved populations - similar to the vision of an engineer with well-developed views of personal and professional social responsibility. Humanitarian Engineering programs are more adept at addressing many ABET 'professional skills', including an understanding of ethical responsibility and of the global and societal impacts of engineering solutions in addition to traditional technical skills ${ }^{10}$.

\section{Research Questions}

The following research questions are the motivations for this paper and study.

1) To what degree does an individual possesses socially responsible ideals and are those beliefs purely personal or are they are also linked to beliefs of professional obligation?

2) Can an effective assessment tool be developed to measure an engineering student's understanding of social responsibility in order to aid with ABET assessment?

It is to this end that a new model describing the development of personal and professional social responsibility has been developed and is presented here within. Additionally, a pilot study was undertaken to develop an assessment tool to accurately capture students' degree of understanding of social responsibility and is rooted in the new model. The first iteration development of this new assessment tool is presented in this paper. Once social responsibility can be measured, future research can use this tool to determine how different learning environments may impact students' understanding of social responsibility; i.e. service-learning (SL) and extracurricular learning through service (LTS) activities.

\section{Conceptual Framework}

The development of personal and professional social responsibility is complex to explain and measure. In the formation of a new model to describe the development of social responsibility, three existing models were used to explain the full developmental process for an individual from the early stages of gaining an awareness of social needs, to a full internalization of a social issue into one's identity. The first model is Schwartz's cognitive model for altruistic behavior development, the second is Ramsey's model for incorporating social parameters into the scientific process, and the third is Delve et al.'s service learning model. 
Schwartz's model describes the cognitive development towards engaging in altruistic behavior through five unique phases ${ }^{11,12}$. The first phase is the Attention Phase and describes the individual's recognition of needs, perceptions about potential action and recognition of one's own ability to engage in these actions. The Motivation Phase categorizes the activation of the individual's value system through feelings of moral obligation to act or not act. The activation of moral obligations could come from internal personal norms or from external social norms. The difference between helping behavior and altruistic behavior, according to Schwartz, lies in which norm, social or personal, respectively, motivated the action. The third phase in the development of altruistic behavior is the Anticipatory Evaluation Phase where the potential costs and benefits of engagement or non-engagement are evaluated. The Defense Phase engages when the potential costs and benefits are determined to be about equal, and therefore don't help in the decision making process, and so a mechanism is engaged to reduce the individual's feelings of moral obligation by changing the perceived aspects of Phase 1 through 3 until an imbalance is found leading to action (or inaction). The final phase is Behavior where the final decision of action or inaction is enacted.

Four of these phases (Attention, Motivation, Anticipatory Evaluation and Behavior) form key elements in the progression of personal social responsibility in the new model. Schwartz's model describes fully the internal moral development of an individual up to the point of taking action, but it fails to discriminate between peripheral volunteering and a centered, deeply intrinsic desire to serve. This model also brushes over the inclusion of an individual's skills in their ability to address certain problems. For these reasons, more models were considered in the development of the Professional Social Responsibility Development Model.

In order to address the development of professional obligation towards altruistic behavior, Ramsey's ${ }^{13,14}$ model for the incorporation of social elements into scientific decisions was consulted. Ramsey highlights the role that science education has in creating active and responsible citizens and uses the Science-Technology-Society (STS) tool, which is similar to Service-Learning, as a vehicle for teaching social responsibility. Quoting Rubba ${ }^{15}$, Ramsey says "the goal of STS education is to help students develop the knowledge, skills and affective qualities needed to take responsible action on myriad social issues facing humankind" (p.238).

To this end, Ramsey sets out six tenets required for creating socially responsible and affective science students: 1) the ability to identify science-related social issues; 2) the ability to analyze issues and identify the "key players" as well as their beliefs and values; 3) the ability to use scientific problem-solving skills to investigate these issues to identify the facts surrounding them and their social, economic, political, legal and ecological ramifications; 4) the ability to evaluate the issues and determine the most effective means of resolving them; 5) the ability to use a decision-making model to develop an action plan that can be implemented to resolve or help resolve the issues; and 6) the ability to execute the plan if it is consistent with the student's personal value system. Tenants 1 through 4 are tied into the new Professional Social Responsibly Development Model to describe the development of professional obligation that must happen if an individual is to tie their feelings of social responsibility into their professional views. 
Finally, to explain the deepening of an individuals' commitment after having started to engage in community service, Delve et al.'s Service Learning Model (SLM) was examined ${ }^{16}$. The Service Learning Model was developed based upon Perry's Cognitive Development Model ${ }^{17}$, Kohlberg's Moral Development Model $^{18}$, and Gilligan's Model of the Development of Women's Moral Judgment $^{19}$ as a theoretical framework from which service-learning interventions could be developed. The Service Learning Model consists of five phases of development. The first phase, Exploration, describes beginning point where an individual is excited to "help people" and be involved, but is naïve about the problems that face others. Generally, at this stage, an individual has not yet developed psychological or emotional ties to a group or cause. Phase 2, Clarification, describes the individuals search for a "good fit" and often searches out multiple service opportunities. In Phase 3, Realization, the individual experiences an "aha" moment where they begin to grasp a larger truth about themselves and about service. Generally at this phase, the individual begins to identify more clearly with a single population or issue. Activation is the $4^{\text {th }}$ Phase in which the individual understands more fully the complexity of issues and the interrelatedness between their service experiences and larger social issues such as classism or racism. At this phase the individual is engaged and often becomes a strong advocate for the particular population that they are working with. In the final phase, Internalization, the individual has fully integrated their community service experience into their lives, to the point at which they adjust their lifestyle and possibly their career, to match the values system they have developed through their service.

Together, these three models of development and service are used to form the Professional Social Responsibility Development Model as a way of explaining the personal and professional progression through social responsibility development. Each of the three models described above contribute a critical aspect, but none of them fully captured the progression from an unaware individual, through the incorporation of professional skills, to taking action. Then from taking action as a peripheral participant into one who has fully integrated their experiences into the fabric of their careers and livelihoods.

\section{The Professional Social Responsibility Development Model}

Using Schwartz's model to explain the personal moral development of helping and altruistic behavior,

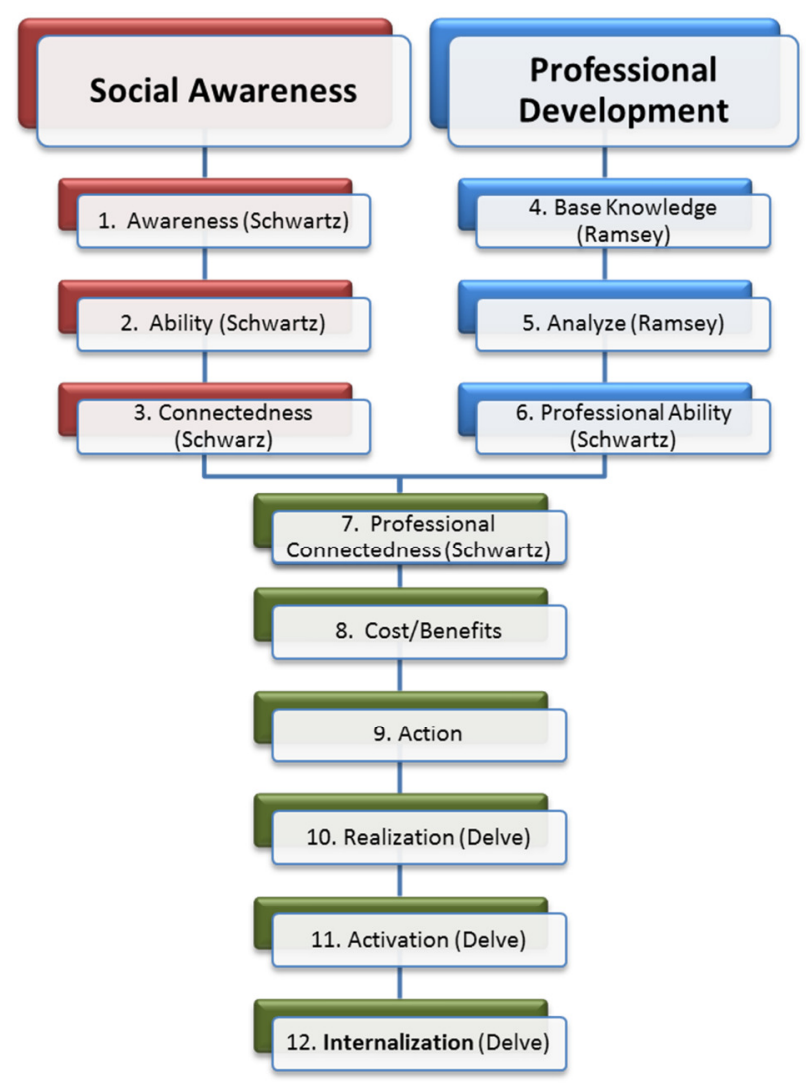

Figure 1. Professional Social Responsibility Development Model 
Ramsey's inclusion of social issues into the scientific process, and Delve et al.'s model to characterize the deepening of commitment and identification with social issues through service, we have developed the Professional Social Responsibility Development Model. This model begins with split paths, one describing the personal development of social awareness and the second describing an individual's professional development (see Figure 1). Starting with split paths allows this model to acknowledge that personal and professional development can happen independently and that it is possible for them never to merge. In other words, an individual may never recognize or adopt a feeling of professional obligation to use their professional skills to serve society. This individuals personal development may advance through the levels of Schwartz's and Delve et al.'s models (except Internalization), but there would never be full integration into their lives because there would be a divorce between their personal and professional values. On the other hand, for an individual to fully develop a deep sense of social responsibility, they must at some point integrate their professional and personal views into a coherent value system. This merging of values is captured through this new model.

The Professional Social Responsibility Development Model is described by twelve steps, beginning with two separate developmental paths of social awareness and professional development described above, which combine to describe continued social responsibility development. The 12 constructs of this model are described below:

\section{- Social Awareness}

1. AWARENESS: awareness that others are in need. This phase is encompassed in Schwartz's Attention Phase.

2. ABILITY: recognition of one's ability to do something to help those who are in need, also included in Schwartz's Attention Phase.

3. CONNECTEDNESS: feeling a sense of responsibility to become involved in social issues. This is based on Schwartz's Motivation Phase.

\section{- Professional Development}

4. BASE KNOWLEDGE: base technical knowledge in profession is acquired, which is seen as a prerequisite from Ramsey's model. This is a critical component to acknowledge the importance of formal education in a professional track in order to gain the skills needed to make significant, technical contributions to society. In this way, value is rightfully placed on formal training in technical skills.

5. ANALYZE: an ability to analyze social issues from a professional perspective, and to identify "key players" and how their beliefs/customs/desires influence the issue, from Ramsey's second tenet.

6. PROFESSIONAL ABILITY: recognition that the professional skills that one has acquired are able to help solve social issues. This step is the key progression needed to be able to incorporate professional development into social responsibility. Up until now, the personal and professional are divorced. It is fully possible for engineers to function purely in 4 and 5 in their career. This construct is an adaptation of the second aspect of Schwartz's Attention Phase and Ramsey's third tenet.

\section{- Combined Social Awareness and Professional Development}

7. PROFESSIONAL CONNECTEDNESS: feeling a sense of obligation to help solve social issues because of professional ability. This construct is also an adaptation of Schwartz's Motivation Phase combined with Ramsey's third tenet. 
8. COSTS/BENEFITS: assessing costs and benefits of personal participation and also of proposed solutions, drawing upon professional expertise for development of social ramifications. This construct combines Schwartz's Anticipatory Evaluation Phase with Ramsey's fourth and fifth tenets which focus on using one's professional skills in decision making

9. ACTION: beliefs are translated into action; volunteerism, pro bono work, mentoring, joining organizations addressing social issues (ESW, EWB, etc.). This construct describes the transition point between Schwartz's model and Delve et al.'s model, and is captured in Ramsey's last tenet. From here, however, it is critical to be able to explain varying degrees of commitment and engagement in actions of service.

10. REALIZATION: there is a personal change in orientation; a connection between social work and personal life is developed. Usually the person has strongly identified with a particular population or issue, drawing directly from Delve et al's third phase.

11. ACTIVATION: participant begins to grasp a larger, more complex understanding of social issues, becoming an advocate for their group, from Delve et al.'s fourth phase.

12. INTERNALIZATION: participant has fully integrated their service experience with their professional life; often affecting personal or professional goals from Delve et al.'s fifth phase.

This model attempts to combine emotional/moral development and professional development, acknowledging that the two have to happen simultaneously, and in fact have to combine at a given stage in order to produce a professional who has fully integrated social responsibility into their value system including their lifestyle and career. It should be noted that since the Schwartz and Delve et al. models are linear, sequential development models, it is also assumed that the Professional Social Responsibility Development Model is also linear and sequential through the independent tracks and then through the combined social development and professional responsibility track. If this is true, it would be expected to see, in general, lower averages in the higher constructs as fewer people would "develop" to that stage. If it is found that individuals can skip lower constructs, but exhibit the characteristics of higher constructs, the linear, sequential assumptions will be revisited and the model will be revised.

\section{Assessment of the Development of Social Responsibility}

\section{Background}

The purpose of this model is to try to capture the paradigm shift that is taking place in engineering students due to engineering education's growing focus beyond just technical engineering skills through an effective assessment tool. The engineering community is familiar with teaching and assessing technical skills and has developed multiple content inventories to that effect ${ }^{20}$. The development of assessment tools to gauge professional skill development, however, has been slow. Shuman et al. ${ }^{21}$ suggest that there are three main hurdles that have prevented many assessment tools of this form from being developed 1) a lack of consensus about the definitions of the professional skills, 2) a lack of understanding of the scope by which each outcome is to be assessed, and 3) the difficult nature of the professional outcomes themselves. 
Despite these difficulties, some assessment tools have been developed focusing on measuring professional skills development. The Modified National Engineering Student's Learning Outcomes Survey (NESLOS) provides a broad sweep of sixteen learning objectives which are tied directly to the ABET "criterion c" metrics ${ }^{22}$. The Engineering Student Attitudes Assessment was also developed with a broad sweep over the ABET metrics and used multiple assessment methods (focus groups, open-ended surveys and structured interviews, and closed-form questionnaires) to gauge freshman engineering students' experiences ${ }^{23}$. Multiple tools have been developed to specifically address the development of ethical skills in engineering $24,25, \& 26$. None of these tools have focused in detail on the learning objectives of understanding global and societal contexts nor have they addressed ethical responsibility from the perspective of professional obligations.

\section{Development of the Engineering Professional Responsibility Assessment tool}

The first iteration development of the Engineering Professional Responsibility Assessment (EPRA) tool was based upon the Professional Social Responsibility Development Model described earlier with each progression in the model comprising a factor of the tool. EPRA was developed with items from existing survey instruments, new items, and two open-ended short answer questions for internal reliability measurements. The majority of the survey tool uses a 7pt Likert-style scale. Students are also asked to select from a list of motivating factors for conducting community service and to report the frequency of volunteering with certain activities such as Habitat for Humanity or EWB since attending college. The motivating factors were given scores for intrinsic or extrinsic motivation.

The "frequency of volunteer" responses were scored using a double weighting system based upon the type of activity and the self-reported participation frequency. The weighting of volunteer activities was based upon typical duration for each activity and the relative difficulty of commitment to engage in even one instance of volunteering. For example donating blood is a relatively quick activity ( $\sim 30$ minutes) and takes very little planning to execute, whereas a Habitat for Humanity Build takes a day or two and requires a certain level of premeditation and coordination. The weighting system for frequency was developed with the understanding that repeated volunteering, such as monthly or weekly, required significantly more commitment than just a single visit and therefore deserved significantly higher weighting. This weighting system is summarized in

Table 1. Finally, demographic information was also collected including gender, age, major, college rank and working status.

The Community Service Attitudes Scale (CSAS) was developed to measure student attitudes about community service, but is not engineering specific ${ }^{27}$. This scales was developed based upon Schwartz's model for altruistic behavior development ${ }^{12}$, similar to the new model presented in this paper. The CSAS is a reliable and valid scale which consists of eight factors that correlate to the developmental stages of Schwartz's model. A first version of the instrument included 59 items on community service attitudes and 5 items on intentions to participate in community service activities, with these items rated on a 5-point Likert scale. The second "final" version of the instrument had 31 community service attitude items and 3 items on intention to participate in community service, and utilized a 7-point Likert scale. Fourteen items from the CSAS were used 
Table 1. Frequency of Volunteering Weighting System

\begin{tabular}{|l|c|}
\hline Volunteer Activity & Weight \\
\hline Donating Blood, In-class Service Learning Project & 1 \\
\hline $\begin{array}{l}\text { Food Bank, Meals on Wheels, Nursing Home, Political Campaign, Big } \\
\text { Brother/Big Sister, Boy \& Girl Scouts, Boys/Girls Club, Soup Kitchen, } \\
\text { Unpaid Tutoring (elementary, secondary, or college) }\end{array}$ & 2 \\
\hline EWB Project & 3 \\
\hline Habitat for Humanity Build & 5 \\
\hline Disaster Relief or International Humanitarian Volunteer & 10 \\
\hline Frequency & \\
\hline Once & 1 \\
\hline Twice & 2 \\
\hline More than Twice but not routinely & 5 \\
\hline Monthly & 20 \\
\hline Weekly & 50 \\
\hline
\end{tabular}

in the EPRA tool, including four of the six items from the Connectedness factor and four of the six items from the Benefits factor were used in a non-Likert section assessing motivations for conducting community service. Although the CSAS was initially validated in 1997 and 1998 using data collected from students ranging from freshmen to graduates predominantly in business, communication, education, or psychology classes ${ }^{27}$, the instrument has more recently been used in engineering ${ }^{28,29}$.

Another assessment tool which was used in the development of EPRA was the Pittsburgh Freshman Engineering Attitudes Survey (PFEAS) ${ }^{30}$. Items from PFEAS were used to address student attitudes about how engineering, as a whole, contributes to society. The PFEAS has been widely used across all engineering disciplines. Other assessment tools that were drawn from in the development of EPRA include the Academic Pathways of People Learning Engineering Survey (APPLES) ${ }^{31}$, the Scale of Service Learning Involvement ${ }^{32}$, NESLOS ${ }^{22}$, the Wabash Student Experiences Survey ${ }^{33}$, the Attitudes Towards Service Learning Survey ${ }^{34}$, the Intercultural Development Inventory (IDI) ${ }^{35}$, and the Sustainable Engineering via ServiceLearning (SESL) survey instrument ${ }^{36}$. Table 6 in Appendix A summarizes the sources of the items used in the development of EPRA.

\section{Fall 2011 Pilot Assessment}

A first version of EPRA was administered to engineering students in Fall 2011 as part of a pilot study at a large, public institution. The study began with an IRB-approved informed consent form. Some students completed hard-copy surveys in-class while other students filled out the survey on-line through SurveyMonkey. Survey questions were IRB approved beforehand. Based on the SurveyMonkey responses, the average time to complete the assessment was 12 minutes $\left(4-21\right.$ minutes $5^{\text {th }}-90^{\text {th }}$ percentile). In total, 616 students completed the survey representing all academic years (Freshman through Graduate) and with a gender distribution of $25 \%$ women, $70 \%$ men and $5 \%$ unreported gender. These students were invited to participate 
based on enrollment in any first-year introductory engineering course (via email) or targeted courses in architectural, civil, environmental, or mechanical engineering. The majority of respondents were from Civil, Environmental or Mechanical engineering, with smaller representations from Aerospace Engineering, Chemical-Biological Engineering and other engineering sub-disciplines. For validity and reliability determination, a sample size of 10 respondents per question was targeted for the 65-question survey. The realized number of responses was slightly fewer than this target, but was considered close enough for validity and reliability purposes. A summary of student responses for each factor is provided in Table 2 .

First, it can be observed that on average the professional skills (factors 4-6) ratings were higher than personal social responsibility ratings (factors 1-3). The professional social responsibility factors (7-12) were lower, possibly supporting the general linear, sequential pattern of the subparts. However, within each of the three sub-parts the factor scores did not show a decreasing pattern as expected with the linear model. Factors $8-12$ (except 10) did show factor averages that spanned the entire 1-7 range, with standard deviations around 1.0, supporting the belief that the sample population wasn't overly biased one way or another due to a particular departmental environment at the pilot institution. It is also worth noting that factor 4 (Base Knowledge) is highly saturated in the average score and with relatively low deviation.

Table 2. Summary of Student Responses

\begin{tabular}{|l|c|c|c|c|c|}
\hline Factor & Scale & $\begin{array}{c}\text { \# of } \\
\text { Items }\end{array}$ & $\begin{array}{c}\text { Average } \\
\text { Score }\end{array}$ & $\begin{array}{c}\text { Standard } \\
\text { Deviation }\end{array}$ & Range \\
\hline 1. Awareness & $1-7$ & 5 & 5.2 & 0.7 & $3.3-7.0$ \\
\hline 2. Ability & $1-7$ & 4 & 5.5 & 0.8 & $2.3-7.0$ \\
\hline 3. Connectedness & $1-7$ & 5 & 5.5 & 0.9 & $2.2-7.0$ \\
\hline 4. Base Knowledge & $1-7$ & 16 & 6.2 & 0.5 & $2.9-7.0$ \\
\hline 5. Analyze & $1-7$ & 6 & 5.4 & 0.8 & $2.3-7.0$ \\
& & & & & \\
\hline 6. Professional Ability & $1-7$ & 4 & 6.2 & 0.7 & $2.3-7.0$ \\
\hline 7. Professional Connectedness & $1-7$ & 6 & 5.6 & 0.8 & $2.7-7.0$ \\
& & & & & \\
\hline 8. Cost/Benefits & $1-7$ & 3 & 4.2 & 1.1 & $1.0-7.0$ \\
\hline 9. Action (Likert Questions) & $1-7$ & 2 & 4.5 & 1.0 & $1.0-7.0$ \\
(Volunteer Frequency Score) & - & - & 39 & 63 & $0-440$ \\
\hline 10. Realization & $1-7$ & 4 & 4.9 & 1.0 & $2.0-7.0$ \\
& & & & & \\
\hline 11. Activation & $1-7$ & 5 & 4.9 & 0.8 & $1.0-7.0$ \\
\hline 12. Internalization & $1-7$ & 5 & 5.2 & 1.0 & $1.7-7.0$ \\
\hline
\end{tabular}

\section{Reliability and Validity}

Twenty-three students took the survey twice within a two week period, allowing for test-retest reliability determination. The Test-Retest Correlation Coefficient was determined using Pearsons's Coefficient of Correlation for each repeated individual over all 65 Likert-style 
questions. Of the 23 repeat respondents, 10 respondents had r-values between 0.6 and 0.8 showing strong correlation and 11 had r-values above 0.8 showing very strong correlation.

Internal Consistency was also examined for each factor using the entire sample set. The calculated Cronbach's Alpha term for each factor is given in Table 3. If removing an item from the factor significantly increased the Cronbach's Alpha term, the item and the revised alpha are also given in the table. Most factors have favorable internal consistency (alpha $>0.6$ ). Factors 8 and 11 have lower internal consistency and will be reexamined in the second round analysis of the EPRA tool. Note that because construct 9 (Action) has only two Likert-style items and is primarily assessed through the volunteer frequency score, internal consistency was not determined for this construct.

Table 3. Factor Reliability Statistics $(n=616)$

\begin{tabular}{|l|c|c|l|c|}
\hline Factor & $\begin{array}{c}\text { \# of } \\
\text { Items }\end{array}$ & $\begin{array}{l}\text { Cronbach's } \\
\text { Alpha }\end{array}$ & Item to remove to increase Alpha & $\begin{array}{l}\text { Revised } \\
\text { Alpha }\end{array}$ \\
\hline 1. Awareness & 5 & 0.731 & & \\
\hline 2. Ability & 4 & 0.828 & & \\
\hline 3. Connectedness & 5 & 0.866 & & 0.736 \\
\hline 4. Base Knowledge & 16 & 0.862 & & $\begin{array}{l}\text { 5e. Courses have } \text { not helped me see the } \\
\text { connections between engineering and } \\
\text { how it affects society }\end{array}$ \\
\hline 5. Analyze & 6 & 0.648 & \\
\hline $\begin{array}{l}\text { 6. Professional } \\
\text { Ability }\end{array}$ & 4 & 0.795 & & 0.809 \\
\hline $\begin{array}{l}\text { 7. Professional } \\
\text { Connectedness }\end{array}$ & 6 & 0.779 & & \\
\hline 8. Cost/Benefits & 3 & 0.413 & & $\begin{array}{l}\text { 10a. How important is the following } \\
\text { statement to your personally: } \\
\text { Influencing politics }\end{array}$ \\
\hline $\begin{array}{l}\text { 10. Realization } \\
\text { 11. Activation }\end{array}$ & 4 & 0.712 & & \\
\hline 12. Internalization & 5 & 0.774 & & \\
\hline
\end{tabular}

Validity for the EPRA tool was determined through content and construct validity methods. Face validity was established in two ways. First, the majority of the questions used in the EPRA tool were taken from existing, relevant assessment tools. Many of those tools were designed to assess engineers and were therefore considered appropriate for this survey. As a second measure of face validity and to ensure that questions that were not originally designed for engineering students would still be applicable, a preliminary survey was administered to six professional engineers in civil engineering, electrical engineering and computer science. The feedback from the preliminary respondents was used to strengthen the survey before administration for the pilot study.

Because the EPRA tool was designed to measure the Professional Social Responsibility Development Model, Confirmatory Factor Analysis was executed on the Fall 2011 dataset to 
determine the validity of the tool. Three model fitting indices were examined (Comparative Fit Index (CFI), Root Mean Square Error of Approximation (RMSEA), and Standardized Root Mean Residual (SRMR)). As a starting point, a 'pure' confirmatory factor model was assumed which included no interrelations between constructs or between items in one construct with another construct. In other words, only items in the Awareness Construct were linked to the Awareness Construct and were not linked to any of the other constructs. This model resulted in a very large $\chi^{2}$, as seen in Table 4 , but did show a fair RMSEA index of fit.

In order to begin accounting for the interrelations between items and constructs, a method described by Karl Jöreskog ${ }^{37}$ and summarized by James Steiger ${ }^{38}$ was used. This method uses a varimax rotation of an m-factor model discovered using Exploratory Factor Analysis. The largest loading for each factor is then determined and all other loading in that row (for that item) are set to zero - resulting in an intermediate confirmatory factor model with many interrelations between items. The factor pattern is then examined with the new model and all non-significant loadings $(|z|<1.96)$ are removed. Multiple iterations of refining the model by deleting nonsignificant interrelations were conducted, resulting in a confirmatory factor model with significant interrelations between construct items and greatly improved model fitting indices which are shown in Table 4. Multiple fit indices are reported as recommended by Hoyle and Panter $^{39}$. Neither the Goodness-of-Fit index, nor the SRMR index meet the threshold to show good fit $\left(>0.90\right.$ and $<0.10$, respectively ${ }^{40}$ ), but the RMSEA index does show good fit with a value less than 0.1 and near 0.05 (showing excellent fit ${ }^{41}$ ). Further investigation into the confirmatory factor model will be conducted to try and improve the indices of fit.

Table 4. Summary of Model-Data Fit in CFA for the EPRA tool factors

\begin{tabular}{|l|c|c|c|c|c|}
\hline Factor & $\chi^{2}$ & $\begin{array}{c}\text { Degree of } \\
\text { Freedom }\end{array}$ & CFI & RMSEA & SRMR \\
\hline $\begin{array}{l}\text { 'Pure' Confirmatory Factor } \\
\text { Model }\end{array}$ & 20,003 & 1,890 & 0.503 & 0.098 & 0.249 \\
\hline $\begin{array}{l}\text { Interrelated Confirmatory } \\
\text { Factor Model }\end{array}$ & 6,825 & 1,635 & 0.820 & 0.056 & 0.164 \\
\hline
\end{tabular}

The interrelations are shown in Table 5 between each factor (columns) and the items in other factors (rows). The values shown are normalized by the number of items in each factor, in other words, the interrelations between the Ability Factor and the items of the AWARE factor (row 1, column 2) is 0.60 , meaning that 3 of the 5 items $(60 \%)$ in the AWARE factor have a path to the Ability factor. As expected, for each factor, the normalized interrelation to the items in that factor is 1.0 , which is seen on the diagonal of the table. Most factors retain significant $(>0.50)$ interrelations to items from other factors, except for the Connectedness, Realization, and Activation factors which remain fairly isolated. Ideally there would be few cross paths between items of one factor with other factors, but because of the complex nature of understanding beliefs of social responsibility, it is understandable that there are cross paths in this initial iteration of the EPRA tool, especially between similar factors such as Awareness and Ability. Future iterations of the EPRA tool will attempt to create more distinct items such that there are fewer cross paths in the Confirmatory Factor Model, especially at opposite ends of the developmental model (Awareness and Internalization). 
Table 5. Normalized Interrelations between Factors for Confirmatory Factor Model

\begin{tabular}{|c|c|c|c|c|c|c|c|c|c|c|c|c|}
\hline & & \multicolumn{11}{|c|}{ Factor } \\
\hline $\begin{array}{l}\text { \# of } \\
\text { Items }\end{array}$ & Factor Items & 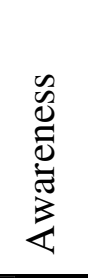 & 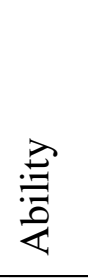 & 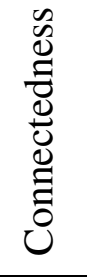 & 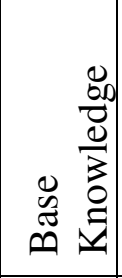 & 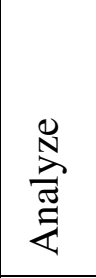 & 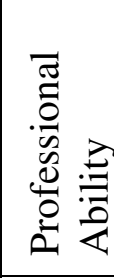 & 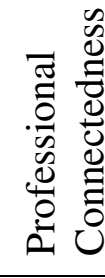 & $\begin{array}{l}0 \\
0 \\
0 \\
0 \\
0 \\
0 \\
00 \\
0 \\
0 \\
0\end{array}$ & 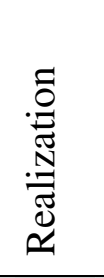 & 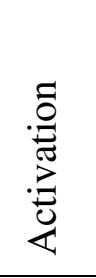 & 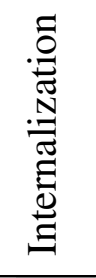 \\
\hline 5 & AWARE & 1.00 & 0.60 & 0.00 & 0.20 & 0.20 & 0.00 & 0.20 & 0.80 & 0.60 & 0.00 & 0.80 \\
\hline 4 & ABILITY & 1.00 & 1.00 & 0.25 & 0.00 & 0.25 & 0.75 & 0.50 & 0.50 & 0.25 & 0.00 & 1.00 \\
\hline 5 & CONN & 0.60 & 0.40 & 1.00 & 0.80 & 0.20 & 0.40 & 0.20 & 0.60 & 0.20 & 0.20 & 0.80 \\
\hline 16 & BASE & 0.13 & 0.31 & 0.19 & 1.00 & 0.88 & 0.44 & 0.69 & 0.06 & 0.13 & 0.44 & 0.13 \\
\hline 6 & ANALYZE & 0.00 & 0.50 & 0.33 & 0.33 & 1.00 & 0.50 & 0.83 & 0.00 & 0.33 & 0.17 & 0.17 \\
\hline 4 & PROFAB & 0.50 & 1.00 & 0.25 & 0.25 & 0.25 & 1.00 & 0.25 & 0.75 & 0.00 & 0.25 & 0.00 \\
\hline 6 & PROFCON & 0.50 & 0.50 & 0.33 & 0.83 & 0.50 & 0.67 & 1.00 & 0.67 & 0.33 & 0.00 & 0.50 \\
\hline 3 & $\mathrm{CB}$ & 0.00 & 0.67 & 0.33 & 0.33 & 0.33 & 0.33 & 0.00 & 1.00 & 0.00 & 0.00 & 0.00 \\
\hline 4 & REAL & 1.00 & 0.50 & 0.25 & 0.50 & 0.00 & 0.25 & 0.25 & 0.50 & 1.00 & 0.00 & 0.75 \\
\hline 5 & ACTIV & 0.80 & 0.80 & 0.00 & 0.80 & 0.20 & 0.20 & 0.00 & 0.60 & 0.60 & 1.00 & 0.80 \\
\hline 5 & INT & 0.80 & 0.40 & 0.00 & 1.00 & 0.60 & 1.00 & 0.40 & 0.20 & 0.40 & 0.00 & 1.00 \\
\hline
\end{tabular}

\section{Conclusions}

In an attempt to describe the personal and professional development of individuals to include beliefs of social responsibility, a new model has been developed. The Professional Social Responsibility Development Model draws from three existing models which describe the personal development of altruistic behavior, the inclusion of social issues into the scientific decision process, and the deepening commitment to social issues that occurs once an individual is engaged in service experiences.

Based on the Professional Social Responsibility Development Model, a survey instrument was designed to assess individuals' degree of understanding of social responsibility - the Engineering Professional Responsibility Assessment (EPRA). A pilot study was conducted and the results were used to determine reliability and validity of the tool. Test-Retest and Internal Consistency methods were used, and showed good reliability for most constructs in the tool. Confirmatory Factor Analysis, using a highly interrelated confirmatory model, showed good fit for one index, but not for the other two indices. Further work will be done, with additional data, in order to attempt to establish stronger validity for the tool. Some items are being removed or re-worded and additional items will be added in an attempt to decrease cross loading between factors. The open ended response related to career aspirations will be changed to better assess what factors influence student perceptions of their future engineering career and other possible sources of beliefs of social responsibility may be explored, including the influence of religion. A new version of the EPRA tool, adjusted based upon the results of the Fall 2011 pilot study, will be used in a Spring 2012 pilot study to obtain a new data set for further analysis and refinement. 


\section{Bibliography}

1. NAE, Educating the Engineer of 2020: Adapting Engineering Education to the New Century, Washington DC: The National Academies Press, 2005.

2. AAEE, "Environmental Engineering Body of Knowledge," American Academy of Environmental Engineers, 2009.

3. ASCE, "Civil Engineering Body of Knowledge for the 21st Century: Preparing the Civil Engineer for the Future, 2nd Edition," ASCE, 2008.

4. ABET, "Criteria for Accrediting Engineering Programs Effective for Evaluation During the 2009-2010 Accredidation Cycle," ABET Engineering Accreditation Commission, 2008.

5. Entrepreneur, "Entrepreneur Encyclopedia: Social Responsibility," 2011. [Online]. Available: http://www.entrepreneur.com/encyclopedia/term/82646.html. [Accessed 21 July 2011].

6. M. Pantazidou and I. Nair, "Ethics of Care: Guiding Principles for Engineering Teaching \& Practice," Journal of Engineering Education, vol. 88, pp. 205-212, 1999.

7. I. Nair, "Ethics of Care," in Encyclopedia of Science, Technology, and Ethics, Detroit, MI, Macmillan Reference USA, 2005, pp. 695-700.

8. C. Gilligan, In a Different Voice: Psychological Theory and Women's Development, Campbridge, MA: Harvard University Press, 1982.

9. R. C. Campbell and D. Wilson, "The Unique Value of Humanitarian Engineering," in Proceedings of the Annual ASEE Conference and Exposition, Vancouver, BC, 2011.

10. B. M. Moskal, C. Skokan, D. Munoz and J. Gosink, "Humanitarian Engineering: Global Impacts and Sustainability of a Curricular Effort," International Journal of Engineering Education, vol. 24, no. 1, pp. 162174, 2008.

11. S. Schwartz, "Normative influences on altruism," Advances in experimental social psychology, vol. 10, pp. 221279, 1977.

12. S. H. Schwartz and J. A. Howard, "Helping and Cooperation: A Self-Based Motivational Model," in Cooperation and Helping Behavior: Theories and Research, New York, Academic Press, Inc., 1982, pp. 327353.

13. J. Ramsey, "A Curricular Framework for Community-Based STS Issue Instruction," Education and Urban Society, vol. 22, no. 1, pp. 40-53, November 1989.

14. J. Ramsey, "The Science Education Reform Movement: Implications for Social Responsibility"," Science 
Education, vol. 77, no. 5, pp. 235-258, 1993.

15. P. A. Rubba, "STS Education: What Researchers Say to Teachers," Social Education, vol. 54, pp. 201-203, 1990.

16. C. L. Delve, S. D. Mintz and G. M. Stewart, "Promoting values development through community service: A design," New Directions for Student Service, pp. 7-29, 1990.

17. W. J. Perry, Forms of Intellectual and Ethical Development in the College Years: A Scheme, New York: Holt, Rinehart \& Winston, 1970.

18. L. Kohlberg, "The Cognitive-Developmental Approach to Moral Education," Phi Delta Kappan, vol. 56, pp. 670-677, 1975.

19. C. Gilligan, In a Different Voice, Cambridge, Mass.: Harvard University Press, 1982.

20. D. L. Evans, G. L. Gray, S. Drause, J. Martin, C. Midkiff, B. M. Notaros, M. Pavelich, D. Rancour, T. ReedRhoads, P. Steif, R. Streveler and K. Wage, "Progress on Concept Inventory Assessment Tools," in Proceedings of the 33rd ASEE/IEEE Frontiers in Education Conference, 2003.

21. L. J. Shuman, M. Besterfield-Sacre and J. McGourty, "The ABET "Professional Skills" - Can They Be Taught? Can They Be Assessed?," Journal of Engineering Education, vol. 94, no. 1, pp. 41-55, 2005.

22. A. Carberry and C. Swan, "Developing an Instrument to Measure the Impace of Service to Technical and Professional Learning Outcomes," in Proceedings of the 2011 ASEE Annual Conference \& Exposition, Vancouver, BC, 2011.

23. M. Besterfied-Sacre, C. J. Atman and L. J. Shuman, "Engineering Student Attitudes Assessment," Journal of Engineering Education, pp. 133-141, 2000.

24. J. Rest, "Development in Judging Moral Issues," University of Minnesota Press, Minneapolis, MN, 1979.

25. L. Shuman, M. Sindelar, M. Besterfield-Sacre, M. Wolfe, R. Pinkus, R. Miller, B. Olds and C. Mitcham, "Assessing Students' Abilities to Resolve Ethical Dilemmas," in Proceedings, 2003 Frontiers in Education Conference, Institute of Electircal and Electronic Engineers, 2003.

26. C.-H. Wu, K. Troboy, T. Cole, L. Cochran and D. Roach, "Does Education Have an Impact on Student Ethical Reasoning? Developing an Assessment of Ethical Reasoning for Engineering and Business Students," in Proceedings of the 2008 Midwest Section Conference of the American Society of Engineering Education, 2008.

27. A. H. Shiarella, A. M. McCarthy and M. L. Tucker, "Development and Construct Validity of Scores on the Community Service Attitudes Scale," Educational and Psychological Measurement, vol. 60, no. 2, pp. 286300,2000 .

28. E. H. Bauer, B. Moskal, J. Gosink, J. Lucena and D. Munoz, "Faculty and Student Attitudes Toward Community Service: A Comparative Analysis," Journal of Engineering Education, vol. 96, no. 2, pp. 129-140, 2007. 
29. A. Bielefeldt, B. Amadei and R. Sandekian, "Community Service Attitudes of Engineering Students Engaged in Service Learning Projects," in Proceedings of the Annual ASEE Conference and Exposition, Honolulu, Hawaii, 2007.

30. J. Hilpert, G. Stump, J. Husman and W. Kim, "An Exploratory Factor Analysis of the Pittsburgh Freshman Engineering Attitudes Survey," in 38th ASEE/IEEE Frontiers in Education Conference, Saratoga Springs, NY, 2008

31. C. J. Atman, S. D. Sheppard, J. Turns, R. S. Adams, L. N. Fleming, R. Stevens, R. A. Streveler, K. A. Smith, R. L. Miller, L. J. Leifer, K. Yasuhara and D. Lund, "Enabling Engineering Student Success: The Final Report for the Center for the Advancement of Engineering Education," Morgan \& Claypool Publishers, San Rafael, CA, 2010.

32. C. Olney and S. Grande, "Validation of a Scale to Measure Development of Social Responsibiltiy," Michigan Journal of Community Service Learning, pp. 43-53, 1995.

33. Center of Inquiry in the Liberal Arts at Wabash Colledge, "Student Experiences Survey," Center of Inquiry in the Liberal Arts at Wabash Colledge, 2007.

34. J. Duffy, L. Barrington and M. A. Heredia Munoz, "Attitudes of Engineering Students from Underrepresented Groups," in Proceedings of the 2011 ASEE Annual Conference \& Exposition, Vancouver, BC, 2011.

35. M. R. Hammer, M. J. Bennet and R. Wiseman, "Measuring intercultural sensitivity: The intercultural development inventory," International Journal of Intercultural Relations, vol. 24, pp. 421-443, 2003.

36. M. McCormick, K. Lawyer, M. Berlin, C. Swan, K. Paterson, A. Bielefeldt and J. Wiggins, "Evaluation of Sustainable Engineering Education via Service Learning and Community Service Efforts," in Proceedings of the Annual ASEE Conference and Exposition, Louisville, Kentucky, 2010.

37. F. Yang-Wallentin, K. G. Joreskog and H. Luo, "Confirmatory Factor Analysis of Ordinal Variables with Misspecified Models," Structural Equation Modeling: A Multidisciplinary Journal, vol. 17, no. 3, pp. 392-423, 2010.

38. J. H. Steiger, "Confirmatory Factor Analysis with R," [Online]. Available: http://www.statpower.net/Content/312/Handout/Confirmatory\%20Factor\%20Analysis\%20with\%20R.pdf. [Accessed 15 December 2011].

39. R. Hoyle and A. Panter, "Writing About Structural Equation Models" in Structural Equation Modeling: Concepts, Issues and Applications, Thousand Oaks, CA, SAGE Publications, Inc., 1995, pp. 158-176.

40. Kenny, David A., "Measuring Model Fit" 2012. [Online]. Available: http://www.davidakenny.net/cm/fit.htm. [Accessed 8 March 2012].

41. Chen, F. et al. "An Empirical Evaluation of the Use of Fixed Cutoff Points in RMSEA Test Statistics in Structural Equation Models", Sociological Methods and Research V. 36, No. 4, pg. 462-494, 2008. 


\section{Appendix A}

Table 6. Engineering Professional Responsibility Assessment Items and Sources

\begin{tabular}{|c|c|c|c|c|}
\hline \# & \multicolumn{3}{|l|}{ Factor/Item } & Source \\
\hline \multicolumn{4}{|c|}{ Factor 1: Awareness } & \\
\hline $1 \mathrm{a}$ & \multicolumn{3}{|c|}{$\begin{array}{l}\text { There are not people in the community who need help. } \\
\text { (Reversed from original) }\end{array}$} & $\begin{array}{l}\text { CSAS, } \\
\text { awareness }\end{array}$ \\
\hline $1 \mathrm{~b}$ & \multicolumn{3}{|c|}{$\begin{array}{l}\text { Cultural differences are less important than the fact that people have } \\
\text { the same needs, interests, and goals in life }\end{array}$} & IDI \\
\hline $1 \mathrm{c}$ & \multicolumn{3}{|c|}{$\begin{array}{l}\text { It is appropriate that people do not care what happens outside their } \\
\text { country. (Reversed from original) }\end{array}$} & IDI \\
\hline $1 d$ & \multicolumn{3}{|c|}{$\begin{array}{l}\text { People in other cultures are more interested than we are in improving } \\
\text { themselves }\end{array}$} & IDI \\
\hline $1 \mathrm{e}$ & \multicolumn{3}{|c|}{ There are needs in the community } & $\begin{array}{l}\text { CSAS, } \\
\text { awareness }\end{array}$ \\
\hline \multicolumn{5}{|c|}{ Factor 2: Ability } \\
\hline $2 \mathrm{a}$ & \multicolumn{3}{|c|}{ I can make a difference in the community } & CSAS, ability \\
\hline $2 b$ & \multicolumn{3}{|c|}{$\begin{array}{l}\text { I can have an impact on solving problems that face my local } \\
\text { community }\end{array}$} & $\begin{array}{l}\text { Attitudes } \\
\text { Towards Service } \\
\text { Learning }\end{array}$ \\
\hline $2 c$ & \multicolumn{3}{|c|}{$\begin{array}{l}\text { My contribution to society will make a real difference } \\
\text { (Original used the word community instead of society) }\end{array}$} & CSAS, ability \\
\hline $2 \mathrm{~d}$ & \multicolumn{3}{|c|}{$\begin{array}{l}\text { I cannot have an impact on solving problems that face underserved } \\
\text { communities internationally. (Reversed from original) }\end{array}$} & $\begin{array}{l}\text { Attitudes } \\
\text { Towards Service } \\
\text { Learning }\end{array}$ \\
\hline \multicolumn{5}{|c|}{ Factor 3: Connectedness } \\
\hline $3 \mathrm{a}$ & \multicolumn{3}{|c|}{$\begin{array}{l}\text { How important is the following statement to your personally: Helping } \\
\text { others who are in difficulty }\end{array}$} & $\begin{array}{l}\text { Wabash Student } \\
\text { Experiences }\end{array}$ \\
\hline $3 b$ & \multicolumn{3}{|c|}{$\begin{array}{l}\text { How important is the following statement to your personally: } \\
\text { Volunteering in a community }\end{array}$} & $\begin{array}{l}\text { Wabash Student } \\
\text { Experiences }\end{array}$ \\
\hline $3 c$ & \multicolumn{3}{|c|}{$\begin{array}{l}\text { I am responsible for doing something about improving society } \\
\text { (Original used the word community instead of society) }\end{array}$} & $\begin{array}{l}\text { CSAS, } \\
\text { connectedness }\end{array}$ \\
\hline $3 d$ & \multicolumn{3}{|c|}{ It is my responsibility to take some real measures to help others in need } & $\begin{array}{l}\text { CSAS, } \\
\text { connectedness }\end{array}$ \\
\hline $3 e$ & \multicolumn{3}{|c|}{$\begin{array}{l}\text { I do not feel any obligations to contribute to society. } \\
\text { (Reversed from original; original used term community instead of } \\
\text { society) }\end{array}$} & $\begin{array}{l}\text { CSAS, } \\
\text { connectedness }\end{array}$ \\
\hline \multicolumn{4}{|c|}{$\begin{array}{l}\text { Factor 4: Base Knowledge } \\
\text { How important are the following skills for a professional engineer? }\end{array}$} & \\
\hline $4 \mathrm{a}$ & Business Knowledge & & Leadership & APPLES \\
\hline $4 \mathrm{~b}$ & Communication & & Life-Long Learning & APPLES \\
\hline $4 \mathrm{c}$ & Conducting Experiments & $4 \mathrm{k}$ & Management Skills & APPLES \\
\hline $4 d$ & Creativity & 41 & Math & APPLES \\
\hline $4 \mathrm{e}$ & Data Analysis & $4 \mathrm{~m}$ & Problem Solving & APPLES \\
\hline $4 \mathrm{f}$ & Design & $4 n$ & Professionalism & APPLES \\
\hline
\end{tabular}




\begin{tabular}{|c|c|c|c|c|}
\hline $4 \mathrm{~g}$ & Engineering Tools & 40 & Science & APPLES \\
\hline $4 \mathrm{~h}$ & Ethics & & Teamwork & APPLES \\
\hline \multicolumn{5}{|c|}{ Factor 5: Analyze } \\
\hline $5 \mathrm{a}$ & \multirow{2}{*}{\multicolumn{3}{|c|}{$\begin{array}{l}\text { How important are contemporary issues for a professional engineer? } \\
\text { How important is cultural awareness/understanding for a professional } \\
\text { engineer? }\end{array}$}} & APPLES \\
\hline $5 b$ & & & & APPLES \\
\hline $5 \mathrm{c}$ & \multicolumn{3}{|c|}{ How important is global context for a professional engineer? } & APPLES \\
\hline $5 \mathrm{~d}$ & \multicolumn{3}{|c|}{ How important is societal context for a professional engineer? } & APPLES \\
\hline $5 \mathrm{e}$ & \multicolumn{3}{|c|}{$\begin{array}{l}\text { Courses have not helped me see the connections between engineering } \\
\text { and how it affects society. (Reversed from original) }\end{array}$} & $\begin{array}{l}\text { Wabash Student } \\
\text { Experiences }\end{array}$ \\
\hline $5 f$ & \multicolumn{3}{|c|}{$\begin{array}{l}\text { Rate your motivation to incorporate societal constraints into } \\
\text { engineering decisions }\end{array}$} & SESL \\
\hline \multicolumn{4}{|c|}{ Factor 6: Professional Ability } & \\
\hline $6 \mathrm{a}$ & \multirow{2}{*}{\multicolumn{3}{|c|}{$\begin{array}{l}\text { Engineers have contributed greatly to fixing problems in the world } \\
\text { My engineering skills are not useful in making the community a better } \\
\text { place. (Reversed from original, and some rewordings) }\end{array}$}} & PFEAS \\
\hline $6 \mathrm{~b}$ & & & & CSAS, ability \\
\hline $6 \mathrm{c}$ & \multicolumn{3}{|c|}{$\begin{array}{l}\text { Technology does not play a role in solving society's problems } \\
\text { (Reversed from original) }\end{array}$} & PFEAS \\
\hline 6d & \multicolumn{3}{|c|}{ Engineers can have a positive impact on society } & \\
\hline \multicolumn{4}{|c|}{ Factor 7: Professional Connectedness } & \\
\hline $7 \mathrm{a}$ & \multicolumn{3}{|c|}{ How important is volunteerism for a professional engineer? } & \\
\hline $7 \mathrm{~b}$ & \multicolumn{3}{|c|}{$\begin{array}{l}\text { Service should not be an expected part of the engineering profession } \\
\text { (Reversed from original) }\end{array}$} & $\begin{array}{l}\text { Attitudes } \\
\text { Towards Service } \\
\text { Learning Survey }\end{array}$ \\
\hline $7 \mathrm{c}$ & \multicolumn{3}{|c|}{ Engineers should use their skills to solve social problems } & $\begin{array}{l}\text { Attitudes } \\
\text { Towards Service } \\
\text { Learning Survey }\end{array}$ \\
\hline $7 \mathrm{~d}$ & \multicolumn{3}{|c|}{$\begin{array}{l}\text { Rate your motivation to use Engineering to help society or solve a } \\
\text { societal need }\end{array}$} & SESL \\
\hline $7 \mathrm{e}$ & \multicolumn{3}{|c|}{ Rate your motivation to use engineering to benefit your community } & SESL \\
\hline $7 \mathrm{f}$ & \multicolumn{3}{|c|}{ Rate your motivation to act responsibly as a citizen and professional } & SESL \\
\hline \multicolumn{4}{|c|}{ Factor 8: Costs/Benefits } & \\
\hline $8 \mathrm{a}$ & \multicolumn{3}{|c|}{$\begin{array}{l}\text { Engineering is more concerned with improving the welfare of society } \\
\text { than most other professions }\end{array}$} & PFEAS \\
\hline $8 \mathrm{~b}$ & \multicolumn{3}{|c|}{ Engineers can have a negative impact on society } & \\
\hline $8 \mathrm{c}$ & \multicolumn{3}{|c|}{$\begin{array}{l}\text { People in most other occupations contribute more to making the world } \\
\text { a better place than engineers. (Reversed from original) }\end{array}$} & PFEAS \\
\hline \multicolumn{4}{|c|}{$\begin{array}{l}\text { Factor 10: Realization } \\
\text { (Note that Factor 9: Action is measured through different means) }\end{array}$} & \\
\hline $10 \mathrm{a}$ & \multicolumn{3}{|c|}{$\begin{array}{l}\text { How important is the following statement to your personally: } \\
\text { Influencing politics }\end{array}$} & \\
\hline $10 \mathrm{~b}$ & \multicolumn{3}{|c|}{$\begin{array}{l}\text { It is not important to me to gain a sense of responsibility by } \\
\text { participating in community service. (Reversed from original; increased } \\
\text { sense removed) }\end{array}$} & $\begin{array}{l}\text { CSAS, } \\
\text { connectedness }\end{array}$ \\
\hline $10 \mathrm{c}$ & \multicolumn{3}{|c|}{ It is important to me to have a sense of contribution and helpfulness } & CSAS, \\
\hline
\end{tabular}




\begin{tabular}{|c|c|c|}
\hline & through participating in community service & connectedness \\
\hline $10 \mathrm{~d}$ & $\begin{array}{l}\text { It is important to provide a useful service to the community through } \\
\text { community service }\end{array}$ & CSAS, norms \\
\hline \multicolumn{3}{|c|}{ Factor 11: Activation } \\
\hline $11 \mathrm{a}$ & $\begin{array}{l}\text { Volunteer experience(s) have changed the way I think about spending } \\
\text { money }\end{array}$ & $\begin{array}{l}\text { Scale of Service } \\
\text { Learning } \\
\text { Involvement }\end{array}$ \\
\hline $11 b$ & $\begin{array}{l}\text { How important is the following statement to your personally: } \\
\text { Influencing social values }\end{array}$ & $\begin{array}{l}\text { Wabash Student } \\
\text { Experiences }\end{array}$ \\
\hline $11 \mathrm{c}$ & $\begin{array}{l}\text { The people who benefit from my volunteer activities do not have } \\
\text { anything to offer me. } \\
\text { (Reversed from original) }\end{array}$ & $\begin{array}{l}\text { Scale of Service } \\
\text { Learning } \\
\text { Involvement }\end{array}$ \\
\hline $11 \mathrm{~d}$ & $\begin{array}{l}\text { I believe that the causes of most social issues are simple } \\
\text { (Reversed from original) }\end{array}$ & $\begin{array}{l}\text { Scale of Service } \\
\text { Learning } \\
\text { Involvement }\end{array}$ \\
\hline $11 \mathrm{e}$ & $\begin{array}{l}\text { I am starting to realize that many volunteer organizations simply put } \\
\text { "band aids" over social problems, rather than change them }\end{array}$ & $\begin{array}{l}\text { Scale of Service } \\
\text { Learning } \\
\text { Involvement }\end{array}$ \\
\hline \multicolumn{3}{|c|}{ Factor 12: Internalization } \\
\hline $12 \mathrm{a}$ & $\begin{array}{l}\text { It is important to me personally to have a career that involves helping } \\
\text { people }\end{array}$ & $\begin{array}{l}\text { Attitudes } \\
\text { Towards Service } \\
\text { Learning Survey }\end{array}$ \\
\hline $12 b$ & $\begin{array}{l}\text { I doubt that volunteer work will ever have much effect on my career } \\
\text { (Reversed from original) }\end{array}$ & $\begin{array}{l}\text { Scale of Service } \\
\text { Learning } \\
\text { Involvement }\end{array}$ \\
\hline $12 \mathrm{c}$ & $\begin{array}{l}\text { I believe that I will be involved in social justice issues for the rest of } \\
\text { my life }\end{array}$ & $\begin{array}{l}\text { Scale of Service } \\
\text { Learning } \\
\text { Involvement }\end{array}$ \\
\hline $12 \mathrm{~d}$ & $\begin{array}{l}\text { I think people like me who are more fortunate in life need to help less } \\
\text { fortunate people with their needs and problems }\end{array}$ & $\begin{array}{l}\text { Scale of Service } \\
\text { Learning } \\
\text { Involvement }\end{array}$ \\
\hline $12 \mathrm{e}$ & $\begin{array}{l}\text { I believe it takes more than time, money, and community efforts to } \\
\text { change social problems: we also need to work for change at a national } \\
\text { or global level }\end{array}$ & $\begin{array}{l}\text { Scale of Service } \\
\text { Learning } \\
\text { Involvement }\end{array}$ \\
\hline
\end{tabular}

